\title{
Taming Currency Swaps to Curb India's Current Account Deficit- A Kindle of Hope
}

\author{
Bhagavan Behera ${ }^{1}$, Rajesh Trivedi ${ }^{2}$ \\ ${ }^{1}$ Head of the Department, Department of Business Studies, Konark Institute of Science and Technology, \\ Bhubaneswar (India) \\ ${ }^{2}$ Assistant Professor, Department of Business Studies, Konark Institute of Science and Technology, \\ Bhubaneswar (India)
}

\begin{abstract}
Current account balance appears to be an impenetrable pecuniary concept. However in the economies that spend extravagantly overseas than they accumulate, the current account is the end at which international economics crash with political veracity. When countries lope outsized discrepancies, business tycoons, trade unions, law-makers, analysts and bureaucrats are customarily brisk to tip reproving fingers at trading partners and lay the blame on unwarranted conventions. At the same time as India's Central government leads off to deal with the economic disorders the country faces, its stance cannot but hinge on the Current Account Deficit (CAD). It is that deficit which is 'fundamental' to rupee's corrosion and prompts collateral consequences that intimidates much harm. The seethe avowal these days is 'currency swaps', an artifact of financial engineering which seems to be the only panacea to treat volatility in the rupee and eventually India's unbridled current account deficit. In this paper I endeavored to seize a closer gaze at the perceived implications of currency swaps and its utilization to curb India's current account deficit.
\end{abstract}

Key words: Currency Swap, Current Account Deficit, Combined Transactions, Dealer Market, Pegged Exchange Rate, Floating Exchange Rate

\section{Introduction}

India's mounting and unrestrained behavior of current account has developed into a matter of grave concern in the aftermath of the recent global economic downturn. The RBI, the GOI and the Economic Think Tanks are concerned over India's overstuffed Current Account Deficit (CAD) which surged to a record high of US $\$ 88.2$ billion (4.8 percent of GDP) in 2012-13. Further the Indian rupee reduced to an ever lifetime low of 68.85 against the US dollar on August 28, 2013. There was a correction of 3.7 percent on the day in its biggest single-day percentage plunge in more than two decades. It is an undeniable veracity that that India is not the only emerging market experiencing a rapid decline in its currency's value. Except the Chinese Yuan and Bangladeshi Taka, most Asian currencies have witnessed sharp depreciation since the beginning of 2013. Nonetheless, the Indian rupee has fared much worse than other emerging market currencies because of its twin deficits - current account and fiscal deficits. This dictates policy interventions not only in the external front, but also at the levels of democratic macroeconomic management of the economy. Despite the fact that the Government of India had intervened to rein in and contain trade deficits all the way through an assortment of programmes and policy changes from time to time, the problems has not been eliminated yet. In a growing developing economy like ours, the repetition of such problems may not entirely be startling, but the unrelenting nature of the problem adversely affects the growth process. Since deficits in the current trade balance constitutes the major components of our BoP deficits, the policies aimed at export promotion and import control are linked with policies to manage the flow of foreign exchange in the economy. Naturally the problem is fundamentally macroeconomic in nature and therefore the influence of domestic macroeconomic variables on country's trade balance and balance of payments cannot be denied.

Because of the sheer size of transactions in the currency market, participants are exposed to currency risk. This is the financial risk that arises from potential changes in the exchange rate of one currency in relation to another. Adverse currency movements can often crush positive portfolio returns or diminish the returns of an otherwise prosperous international business venture. The currency swap market is one way to hedge that risk.

Swaps are privately bargained tailor-made contracts. In a currency swap, one party agrees to exchange principal and make regular interest payments in one currency to a counter party for principal and periodic interest payments in another currency. Swaps are handy in hedging exchange rate and interest rate risks by captivating the advantage of arbitrage openings that crop up due to the prevailing imperfections in capital markets. 
The objectives of this study are:

* To present an overview of currency swaps, and analyze the participants in currency swaps

* To study in detail the basic types of swaps and creation of synthetic instruments

* To emphasize the need for a currency-swap deal

* To best part the pros and cons of currency swap deals

* To catalog most recent currency swap deals (2012-2013)

* To itemize Chinese experience

* To evaluate the relevance of currency swaps to India

\section{Meaning and Definitions of Currency Swap}

A swap is an agreement between two parties to swap over series of cash flows for a preordained period of time. It is a kind of financial transaction which has many variations, typically highly complex. It involves a simultaneous exchange of assets (the swap) by counterparties for other different assets of comparable value. The assets may be commodities or they may be financial instruments involving interest rates, cash flows, foreign exchange, debts or equities. As a rule, at the time the contract is initiated, at least one of these series of cash flows is determined by a random or uncertain variable, such as an interest rate, foreign exchange rate, equity price or commodity price. Theoretically, one may view a swap as either a portfolio of forward contracts, or as a long position in one bond coupled with a short position in another bond. In addition to financial profits, the swaps have many purposes such as limiting risks, overcoming restrictions in certain markets, or balancing portfolios. A currency swap is a financial instrument that helps parties swap notional principals in different currencies and thus pay interest payments on the received currency. Alternatively a currency swap can be portrayed as a foreign-exchange agreement between two institutions to exchange aspects (namely the principal and/or interest payments) of a loan in one currency for equivalent aspects of an equal in net present value loan in another currency.

\section{Definitions:}

* Merriam-Webster dictionary defines a swap as 'to replace (something) with something else' or 'to give something to someone and receive something in return' or 'to trade or exchange (things)'

* A swap is an exchange of cash flows over time between two counter parties. (Smith et al: 252)

* Traditionally, the exchange of one security for another to change the maturity (bonds), quality of issues (stocks or bonds), or because investment objectives have changed. Recently, swaps have grown to include currency swaps and interest rate swaps. (Investopedia)

* A foreign exchange swap is an agreement between two parties to exchange a given amount of one currency for another and, after a period of time, to give back the original amounts swapped. (Eiteman)

* Foreign Currency Swap is an agreement to make a currency exchange between two foreign parties. The agreement consists of swapping principal and interest payments on a loan made in one currency for principal and interest payments of a loan of equal value in another currency. (Investopedia)

In a currency swap, the parties to the contract exchange the principal of two different currencies immediately, so that each party has the use of the different currency. They also make interest payments to each other on the principal during the contract term. In many cases, one of the parties pays a fixed interest rate and the other pays a floating interest rate, but both could pay fixed or floating rates. When the contract ends, the parties reexchange the principal amount of the swap. In the beginning, currency swaps were used to give each party access to enough foreign currency to make purchases in foreign markets. Increasingly, parties arrange currency swaps as a way to enter new capital markets or to provide predictable revenue streams in another currency.

\section{Nascence of Currency Swaps}

The brainwave of financial swaps was crafted in the UK as a mechanism of evading foreign-exchange controls in the 1970's, which were aimed to avert an outflow of British Capital. At that time, the British government levied on foreign exchange transactions involving British pounds to make outflow of capital more costly in order to stimulate domestic investment. During that period, companies recurrently exploited successive loans to avoid such taxes. The mechanism of successive loans is: they involved two companies domiciled in two different countries. One company agreed to borrow funds in its own country and then lend those borrowed funds to the other company. The second company, in return, borrowed funds in its own country and lent them to the first company. By doing so, both companies were able to access the foreign capital market without formal exchanges of currencies and thus avoided any foreign exchange taxes.

This trouble-free arrangement later developed into more sophisticated cross currency swaps and interest rate swaps with banks and investment houses as middlemen to bridge counterparties who needed these arrangements. The first formal currency swap, as opposed to the then used parallel loans structure, was transacted by Citicorp International Bank for a \$US 100,000,000 10 year US Dollar Sterling swap between 
Mobil Oil Corporation and General Electric Corporation Ltd (UK). The concept of the interest rate swap was developed by the Citicorp International Swap unit but cross-currency interest rate swaps were introduced by the World Bank in 1981 to obtain Swiss francs and German marks by exchanging cash flows with IBM. This deal was brokered by Salomon Brothers with a notional amount of $\$ 210$ million and a term of over 10 years.

\section{Mechanics of Currency Swap}

The diverse requirements of corporate treasurers, bank liability managers, finance ministers, and portfolio managers account for the rapid growth of the swap market. Basically, the currency swap can be subdivided into:* Fixed rate currency swap ** Currency coupon swap

4.1.1. Fixed Rate Currency Swap: A fixed rate currency swap involves exchange between two counterparties of fixed rate of interest in one currency in return for fixed rate of interest in another currency. It basically involves three steps: initial exchange of principal, periodic interest payment and re-exchange of principal on maturity. The use of currency swaps can be demonstrated with the following example. An US multinational wants to finance the expansion plans of its subsidiary in India using its INR funding pool. An intermediary (bank) can suitably structure the deal so that the intercompany loan can be made at an attractive INR interest rate. This is exactly the kind of problem which currency swap solves. The benefits are twofold: firstly, the US parent can ensure that it gets to borrow at the most competitive rates and secondly, it minimizes foreign Currency risk.

Initial Exchange of Principal: The bank exchanges with the US parent an amount of INR equal to the principal of the intercompany loan in return for an equivalent amount of US dollars based on the spot rate. The INR amount is then passed on by the US parent to its Indian subsidiary by means of an intercompany loan.

Periodic Interest Payments : As time passes, the US parent then pays fixed INR as interest regularly to the bank (matched with the payment dates and amounts underlying the intercompany loan) in return for receiving fixed US dollar interest.

Re-exchange of Principal on Maturity: At maturity, the Indian subsidiary repays the INR principal amount which is passed on to the bank in exchange for the US dollar principal amount.

4.1.2. Currency Coupon Swap: A currency coupon swap is a combination of interest rate swap and fixed rate currency swap. The only difference between this and the earlier fixed rate currency swap is that the fixed interest rate in one currency is exchanged for floating rate interest in another currency. Let us examine how this works by means of an example. An US firm/corporation wants to enter into a major leasing contract for a capital project to be located in India. Assume that the prevailing tax laws of India provide tax advantages for lease contracts in INR. The American corporation wants to take advantage of the tax laws as it would reduce its lease rentals. On the flip side, designating a lease contract in INR would expose it to risk in fluctuations of both interest rates and exchange rates. Now, a bank can suitably structure a currency coupon swap to enable the US Corporation to obtain cost benefits available from the Indian lease and at the same time convert the underlying lease finance into a fully hedged fixed rate dollar liability. The bank pays the US Corporation on an operating basis the accurate amount due in INR based on Indian lease in return for the corporation paying an amount of fixed US dollars to the bank. The bank is hedged by entering into a series of currency coupon swaps of different maturities and principal amounts to match the structure of payments of the US Corporation.

A quick comparison between the fixed rate currency swap and currency coupon swap reveals that the risk could be slightly less in the latter. A fixed rate currency swap is exposed to:* Exchange rate movements, * Interest rate movement in currency $1, *$ Interest rate movement in currency $2, *$ Time to maturity.

The value of the contract at any point in time is the difference between the contracted and the current market exchange and interest rates. But, in the case of the currency coupon swap, the floating rate payment is reset and floating payment principal is not dependent upon long-term interest rates and is valued closer to the exact principal amount. The exchange rate exposure is the same for these two types of swaps. The interest rate exposure could be potentially higher in case of fixed rate currency swaps should the interest rates move in opposite directions. In the currency coupon contract, as the interest rate is set at regular intervals rather than at the end of transaction, it is more efficient.

\subsection{Simulated Examples of Basic Currency Swaps:}

There are four ways of basic currency swaps: fixed for fixed, fixed for floating or floating for fixed and floating for floating. Such deals are motivated by comparative advantage.

Fixed exchange rate on both the currencies: For example, a U.S. Company (Party A) that is looking to open up a plant in India where it's borrowing costs is higher than at home. Assuming a 1/60 (USD/INR) exchange rate, the U.S. Company needs 120 million INR to complete an expansion project in India. The company can borrow 120 million INR at $8 \%$ in India, or \$2 million at 7\% in the U.S. The company borrows the \$2 million at 
$7 \%$, and then enters into a swap to convert the dollar loan into INR. The counterparty of the swap may likely be an Indian company (Party B) that requires $\$ 2$ million in U.S. funds. Likewise, the Indian company will be able to attain a cheaper borrowing rate domestically than abroad - let's say that the Indians can borrow at $6 \%$ within from banks within the country's borders. Let's take a look at the physical payments made using this swap agreement. At the outset of the contract, the Indian company gives the U.S. Company the 120 million INR needed to fund the project, and in exchange for the 120 million INR, the U.S. Company provides the Indian counterparty with $\$ 2$ million. Subsequently, every six months for the next three years (the length of the contract), the two parties will swap payments. The Indian bank pays the U.S. company the product of $\$ 2$ million (the notional amount paid by the U.S. company to the Indian bank at initiation), 7\% (the agreed upon fixed rate), and .5 (180 days / 360 days). This payment would amount to $\$ 70,000$ ( $\$ 2$ million $\times 7 \%$ x .5).

The U.S. company pays the Indian bank the product of 3120 million INR (the notional amount paid by the Indian bank to the U.S. company at initiation), $6 \%$ (the agreed upon fixed rate), and .5 (180 days / 360 days). This payment would amount to $36,00,000$ INR (120 million INR x 6\% x .5). The two parties would exchange these fixed two amounts every 6 months. 3 years after initiation of the contract, the two parties would exchange the notional principals. Accordingly, the U.S. Company would pay the Indian company 120 million INR and the Indian company would pay the U.S. Company $\$ 2$ million.

Fixed exchange rate on one currency and a floating exchange rate on another currency and viceversa: Using the example above, the U.S. Company (Party A) would still make fixed payments at $6.0 \%$ while the Indian bank (Party B) would pay a floating rate (based on a predetermined benchmark rate, such as Mifor (Mumbai Interbank Forward Offer rate)). These types of modifications to currency swap agreements are usually based on the demands of the individual parties in addition to the types of funding requirements and optimal loan possibilities available to the companies. Either party A or B can be the fixed rate pay while the counterparty pays the floating rate.

Floating exchange rate on both the currencies: Both the U.S. company (Party A) and the Indian bank (Party B) make floating rate payments based on a benchmark rate. (Note: In the above examples, transaction costs have been omitted to simplify explaining payment structure).

\subsection{Utility of Currency Swaps:}

Currency swaps have the following main uses:

* To convert a liability in one currency into a liability in another currency.

* To convert an investment (asset) in one currency to an investment in another currency

* To promote of bilateral trade and facilitate direct investment between the two countries in respective local currencies.

* To secure cheaper debt (by borrowing at the best available rate regardless of currency and then swapping for debt in desired currency using a back-to-back-loan).

* To hedge against (reduce exposure to) exchange rate fluctuations

\subsection{Salient Features of Swaps:}

* Combined Transactions: A Currency Swap operation is a combination of two transactions: a spot and a forward.

* No cash up front: No cash-up-front is required at the time of entering the contract. Up-front payment is anything of value, usually money, delivered at the time a contract is signed.

* Notional principal: The amount is notional because there is no exchange of actual principal.

* Settlement date, settlement period: Settlement date and settlement period is allotted to the parties of a transaction to satisfy the transaction's obligations.

* Credit risk: The risk of loss of principal or loss of a financial reward stemming from a borrower's failure to repay a loan or otherwise meet a contractual obligation is inherent.

* Dealer market: Finding the right counterparties is usually done through swap dealers. They make the finding of the right counterparties a much easier job and substantially enhance the market liquidity. These dealers will charge market participants a fee-usually in the form of bid/ask spread.

* Spot value date/ forward value date: This product consists in sale of one currency for another currency with settlement no later than on the spot value date and buyback/resale with settlement on the forward value date.

* Concurrent Exit: Both transactions are concluded at the same moment

\subsection{Benefits of Currency Swaps:}

The benefits of currency swaps are:

* No cash up front and upfront cost

* Help portfolio managers regulate their exposure to interest rates 
Speculators can benefit from a favorable change in interest rates

* Reduce uncertainty associated with future cash flows as it enables companies to modify their debt conditions. Reduce costs and risks associated with currency exchange.

* Swap arrangements reduce or eliminate convertibility risk and transfer risk

* Client is fully hedged against foreign exchange risks in terms of both principal and coupons as the swap locks in current market rate

* Companies having fixed rate liabilities can capitalize on floating-rate swaps and vice versa, based on the prevailing economic scenario

* One distinct advantage of the swap is greater recognition of currencies involved in such transactions. Therefore, currency swap in the rupee with our counterparts will help in internationalization of the rupee

* Such mechanisms do provide a stable regime to importer and exporter helping them to concentrate on factors other than currency risk

\subsection{The Murky Side of Currency Swaps:}

The drawbacks of currency swaps are:

* Highly credit intensive

* Exposed to credit risk as either one or both the parties could default on interest and principal payments

* Liability risk as well as interest rate risk i.e. swap payments are due when floating rate on the payment leg is higher than that the receiving leg

* Vulnerable to the central government's intervention in the exchange markets. This happens when the government of a country acquires huge foreign debts to temporarily support a declining currency which leads to a huge downturn in the value of the domestic currency.

\subsection{The Inherent Danger:}

The danger in currency swap usage comes from the interaction of three factors that form a potentially lethal cocktail if the risks are not properly understood and managed.

* The first is leverage. Currency swaps are highly levered instruments. For example, futures contracts in practice often have margin requirements of around $10 \%$ (or less) of the value of the contract, yet give onefor-one exposure to changes in the futures price, so provide 10 or more of leverage. Leverage creates the potential for large gains but also large losses if the market moves in the wrong direction.

* The second is volatility; Market volatility compounds the effect of leverage. As volatility in the price of the underlying increases and unexpectedly large price movements occur, the impact of leverage gets exacerbated leading to potentially larger losses on the downside.

* The third is (il) liquidity. Periods of market turmoil are often accompanied by not only higher volatility but also liquidity drying up selectively. This makes it harder to exit unprofitable strategies (or even to hedge the derivative with the underlying), increasing the risk of the derivatives position.

Almost every major derivatives-related corporate debacle can be traced back to a combination of these factors. Here is a small sampling of some famous cases. All but one-the exception is Metallgesellschaft - involved speculative trading, and in all cases, a sharp unexpected market move led to losses that bankrupted the concerned entity. Further detail on the cases may be found in Sundaram and Das (2010, op. cit.).

4.8. Exiting a Swap Agreement: Sometimes one of the swap parties needs to exit the swap prior to the agreedupon termination date. This is similar to an investor selling an exchange-traded futures or option contract before expiration. There are four basic ways to do this:

* Buy out the Counterparty: Just like an option or futures contract, a swap has a calculable market value, so one party may terminate the contract by paying the other this market value. However, this is not an automatic feature, so either it must be specified in the swaps contract in advance, or the party who wants out must secure the counterparty's consent.

* Enter an Offsetting Swap: For example, Company A from the interest rate swap example above could enter into a second swap, this time receiving a fixed rate and paying a floating rate.

* Sell the Swap to Someone Else: Because swaps have calculable value, one party may sell the contract to a third party. As with Strategy 1, this requires the permission of the counterparty. 
* Use a Swaption: A swaption is an option on a swap. Purchasing a swaption would allow a party to set up, but not enter into, a potentially offsetting swap at the time they execute the original swap. This would reduce some of the market risks associated with Strategy 2.

\section{The Overdue Policy Response by the GOI to Curb CAD}

During July-December 2013, the following measures were taken by the GOI to stem the depreciation of rupee and contain the $\mathrm{CAD}$ :

The duties on the import of gold, silver and platinum were increased to 10 percent.

* The limits on foreign ownership of sensitive sectors (such as telecoms and insurance) were further liberalized.

* New restrictions were imposed on Indian residents seeking to send money abroad to buy property.

* In mid-August, the existing limits on overseas direct investments by Indian companies were substantially reduced. However, this policy was withdrawn by the new governor of RBI on September 3.

* The interest rates limits for deposits meant for non-resident Indians were liberalized.

* New restrictions on open interest on USD-INR trades were imposed.

* Banks have been banned from trading in domestic currency futures and the exchange-traded options market on their own. Banks can only trade on behalf of their clients.

* The margin requirement on the domestic dollar-rupee forward trade was increased to 100 percent of the traded amount, which means investors will have to give the entire amount of the transaction upfront.

* The state-owned oil marketing companies (OMCs) - which buy dollars to finance their imports - were asked to trade only with a single state owned bank.

It is surprising to note is that the above-mentioned policy measures failed to arrest the sliding value of the rupee in the currency markets.

\section{India's CAD and Her Present Plan}

India has signed currency swap agreements with Japan (\$15 billion) and Bhutan (\$100 million). China has shown active interest in entering into such an agreement with India but it is yet to be signed. Currently, the government of India is exploring possibilities of entering into currency swap agreements with trade partners aiming to shore up exports and bring down trade deficit, which is putting pressure on the rupee. If Indian importers are able to settle bills in rupees, it will lessen demand for dollars and will reduce the pressure on the rupee in the currency market. Trading partners that accept rupee will use it for importing goods from India. However, how far will such measures help stabilize the rupee is debatable. For example, what will be the incentive for our trading partners for entering into such an agreement? Also, since India runs a large deficit on the current account, the impact on the total demand for foreign currency could be minimal.

India is in talks with major trading partners, including Singapore and Japan to accept payment in rupee for a part of their exports. The move will also make the rupee more acceptable in international trade. The assumption is that the rupee is now acceptable de facto as a unit of currency by traders in markets like Singapore and so the barter trade will give it legitimacy. It is one more step to push the rupee closer to capital account convertibility.

It also plans to target oil producing countries such as Venezuela and Iraq, too, for a similar arrangement. But while Iran is a special case, Iraq or Saudi Arabia has problems as they hardly import anything from India. So the rupee chest will be useless for them. It is also reported that China has also shown keenness to start a Yuan-rupee trade while Japan, too, is largely willing to go ahead with such a plan. A larger volume of trade in rupee will expand the onshore market for the currency. Available literature also shows that typically for India and China, it is the offshore market that determines how the domestic currency behaves compared with economies that allow more convertibility, like Brazil and South Korea.

\section{Perceived Implications of Currency Swaps}

7.1. DOLLAR DEMAND WILL DIP: In actual practice, once currency swap is established, for instance, between India and another country, the exporter will borrow in the currency of importer, sell the currency against the rupee and utilize the rupee for its local operations. On the due date of contract, the exporter will receive the currency of importer from the buyer and pay off the importing currency locally. Same concept will mutatis-mutandis apply to Indian importer.

Therefore, entering into a currency swap will definitely reduce the demand for dollars, particularly when such arrangements are worked out with countries with whom a large trade deficit exists. From that perspective, India can look for such arrangements with China, Saudi Arabia, Iraq, Indonesia, Kuwait, Qatar, Australia and Venezuela, etc., with whom we are running a trade deficit of $\$ 10$ billion plus. Even in the case of 
these countries, we can give priority to those from whom investment is expected in India so that the swap could also be utilized for encouraging such investments as well. However, one has to be careful to see that such swap agreements, if with many trading partners, terminate at sizable intervals so that no adverse impact is witnessed when they mature. One of the flaws of a local currency settlement mechanism is that it may accentuate trade deficit with a partner country if the domestic industry is not competitive.

7.2. INTERNATIONALISATION: In most swap arrangements, the exchange rate is determined and a fixed exchange rate may provide impetus to imports, particularly when other currencies are depreciating. However, whether the deficit increases the overall trade deficit or simply shifts imports from countries which are outside the swap mechanism to countries which are under the swap mechanism needs to be examined closely.

One cannot draw a parallel with the Rupee Trade Arrangement which we have worked out with Iran as that arrangement is in a specific situation and can be treated as a one-way swap. Its experience cannot be a guiding factor for bilateral swap arrangements.

The major benefit from direct convertibility of the currencies is the reduction in transaction and hedging costs it would facilitate by removing the necessity of involving a third currency, generally the US dollar, in foreign exchange transactions. Such mechanisms do provide a stable regime to importer and exporter helping them to concentrate on factors other than currency risk.

One distinct advantage of the swap is greater recognition of currencies involved in such transactions. Therefore, currency swap in the rupee with our counterparts will help in internationalization of the rupee. This has prompted China to enter into currency swap agreements with over 25 countries. China feels that these arrangements will not only help in internationalization of the Yuan but will also increase its clout in the region. Since this would be a new mechanism where we hardly have any experience in the past, it is better that it is implemented in a gradual way, starting with one or two countries on a pilot basis and based on experience so gained, it may be later extended to other identified countries.

\section{Most Recent Currency Swap Deals (2012-2013)}

* Japan nearly doubled its currency swap with Indonesia to $\$ 22.76$ billion in a deal aimed at providing an extra cushion against potential disruptions when the U.S. Federal Reserve begins tapering its massive monetary stimulus.

* Japan also agreed to double its currency swap with Philippines to $\$ 12$ billion, while agreeing to re-enter a swap deal with Singapore at $\$ 3$ billion.

* India and Bhutan signed a currency swap agreement for up to $\$ 100$ million to further economic cooperation between the two countries. The currency swap arrangement was signed between the Reserve Bank of India (RBI) and the Royal Monetary Authority of Bhutan (RMAB).

* With the rupee around 65 a dollar in recent times, New Delhi enlarged its agreement with Tokyo to swap the Indian currency with dollars from $\$ 15$ billion to $\$ 50$ billion till December 2015. Japan, too, can exchange the yen for dollars, according to the arrangement. The two governments decided to expand the current bilateral currency-swap arrangement from $\$ 15$ billion to $\$ 50$ billion.

* China and the European Central Bank have signed a currency swap agreement worth 350bn yuan $(\$ 57 \mathrm{bn}$; $£ 36 b n$ ). The deal is one of the largest for China as it looks to build a more international role for the yuan. It will last for three years and can be extended if both parties agree.

* The Bank of England and its Chinese counterpart have signed a deal likely to boost trade between the UK and China in the Yuan. The Bank and the People's Bank of China have signed a three-year currency swap arrangement worth 200bn Yuan (£21bn, \$33bn). The UK is looking to become a centre for the Chinese currency, also known as the Renminbi.

* China and Brazil have signed a currency swap deal, designed to safeguard against future global financial crises. The pact will allow their central banks to swap local currencies worth up to 190bn Yuan or 60bn Reais (\$30bn; £20bn). The agreement was signed on the sidelines of the fifth Brics (Brazil, Russia, India, China and South Africa) summit being held in Durban, South Africa.

* South Korea and Malaysia signed a currency swap agreement worth $\$ 4.7$ billion in a move to encourage bilateral trade and help curb currency swings. The latest agreement allows the two Asian nations to purchase and repurchase each other's currency of up to 5 trillion won ( $\$ 4.7$ billion), or 15 billion ringgit. The deal - valid for three years and renewable upon agreement - will allow greater flexibility for businesses to use local currencies for trades that have been commonly settled in US dollars.

* China and Singapore doubled a currency swap agreement to 300 billion Yuan ( $\$ 48.3$ billion) after the citystate became the third offshore center for the Chinese currency.

* The Bank of Japan, U.S. Federal Reserve, the European Central Bank, the Bank of England and the central banks of Canada and Switzerland converted their "temporary bilateral liquidity swap arrangements" into standing arrangements that "will remain in place until further notice". 


\section{Lesson from China's Experience}

Prior to its recent agreement with the ECB in 2013, China has concluded bilateral currency swap agreements with 22 other countries or territories of the size of more than RMB2.2 trillion (about US $\$ 360$ billion). Except for the U.S. Federal Reserve, most of the world's influential central banks have agreed to currency swaps with China, including the ECB, Bank of England and Bank of Japan, and London has become a leading offshore RMB trading center outside of China. It is expected that the BCSA (Bilateral Currency Swap Agreement) could offer further liquidity to the RMB markets in the Euro zone, encourage the use of RMB in foreign markets, provide more convenience in trade and investment between the EU and China, and also strengthen precautionary measures for a potential financial crisis. The conclusion of the arrangement is also another big step for RMB internationalization.

ASEAN and China have agreed to utilize a bilateral currency swap arrangement to facilitate the direct use of Renminbi and other local ASEAN currencies for trading, so that trade between them did not depend on a third country's currency (the US dollar). This step is a response to the global situation and with regard to the stability of the overall global currency. It would in a way reduce currency fluctuation that otherwise would be created by importers or exporters of two sides. China and ASEAN strive to sustain the momentum of high growth, and survive the uncertainty in the global economy, although trade may not be at its strongest due to the current global economic situation.

Eight years after China began exchange rate reform, the Chinese currency Renminbi (RMB), or the Yuan, has advanced 34 percent against the U.S. dollar. The Yuan also gained some 20 percent against the euro over the past eight years. China removed the Yuan's peg to the greenback on July 21, 2005, and moved into a managed floating exchange rate mechanism based on market demand and supply, with reference to a basket of currencies.

The reform has over the years changed many aspects of the Chinese economy. A rising Yuan has reshaped the export businesses in China, the world's largest exporter. As the currency appreciated at an annual pace of $4 \%$, some export companies with a low profit margin of less than 10 percent were forced out of business.

\section{CHINA'S CURRENCY SWAP DEALS WITH ITS COUNTERPARTS IN 2013}

\begin{tabular}{|c|c|c|c|}
\hline COUNTRY & SIZE (BILLION RMB) & DATE OF SIGNING & PERIOD OF VALIDITY \\
\hline EU & 350.00 & Oct.9, 2013 & 3years \\
\hline INDONESIA(Renewal) & 100.00 & Oct.2, 2013 & 3years \\
\hline ICELAND(Renewal) & 3.50 & Sept.30, 2013 & 3years \\
\hline ALBANIA & 2.00 & Sept.12, 2013 & 3years \\
\hline HUNGERY & 10.00 & Sept.9, 2013 & 3years \\
\hline UK & 200.00 & June 22, 2013 & 3years \\
\hline BRAZIL & 190.00 & March 26, 2013 & March 7, 2013 \\
\hline SINGAPORE & 300.00 & & \\
\hline
\end{tabular}

Table: 1 Sources: http://www.china-briefing.com

\section{Conclusion and Suggestions}

The current policy challenges revolve around the fact that whenever there are external shocks hitting the economy and driving prices from the supply side, and there are also imbalances in the economy, these are reflected in exchange rate movements. Consequently, policies and programmes that support the growth of exports as well as the economy's productive capacity remain the main sustainable solution to narrowing the current account deficit and dampening its effects on the exchange rate movements, and hence domestic price stability.

An economic boom fueled by short-term capital inflows and debt-driven consumption is a recipe for currency crash. India's external sector vulnerability is a symptom of a much deeper malaise in overall development strategy and domestic policymaking. Despite the deterioration in major indicators of external sector vulnerability, the policymakers remain complacent in defending India's growth story. There are no quick fixes to country's imbalanced external sector and the Indian economy remains vulnerable to external shocks and global liquidity conditions. Some analysts believe that India can rely on its foreign exchange reserves of \$275 billion to arrest the currency fall. But India's short-term external debt has already reached an alarming level. 
According to the official statistics, India's short-term external debt stood at \$116 billion in March 2013 and the ratio of volatile capital flows (consisting of short-term debt and portfolio investments) to country's foreign exchange reserves was as high as 96 percent. At current levels, the foreign exchange reserves can barely meet the country's import bill for seven months. Secondly, India should immediately work out modalities for trading of goods in local currencies. India could begin trading in local currencies with BRICS partners and Asian countries. Russia, Malaysia and some other countries have expressed interest in trading in local currencies with India.

Lastly, the Indian authorities should not falter to impose capital controls as a macroeconomic policy tool to protect the domestic economy from a sudden capital flight. In this regard, capital controls imposed by Malaysia and Iceland on the capital outflows are worth examining.

\section{REFERENCES}

[1] Asim K. Karmakar (2010) Balance of payments: Theory and policy- The Indian Experience, Deep \& Deep Publications Pvt. Ltd, New Delhi, Edition, Page no.5

[2] http://www.teachmefinance.com/Financial_Terms/swap.html

[3] http://www.merriam-webster.com/dictionary/swap

[4] http://www.investopedia.com/articles/optioninvestor/07/swaps.asp

[5] http://en.wikipedia.org/wiki/Currency_swap

[6] http://financial-dictionary.thefreedictionary.com/Currency+Swap

[7] http://www.finpipe.com/currswaps.htm

[8] Milton Keynes (2008), Financial Management Study Manual - ICAEW (second Ed.). ICAEW, pp, 462-3. ISBN 978-1-84152-569-3

[9] http://www.isda.org/educat/faqs.html\#22

[10] http://www.chinadaily.com.cn/china/2009-03/31/content_7635007.htm

[11] 'China signs 700 mln Yuan currency swaps deal with Uzbekistan'. Reuters. 2011-04-19

[12] http://uzpedia.blogspot.com/2011/04/uzbekistan-signs-currency-swap-deal.html

[13] http://www.ft.com/intl/cms/s/0/015f526a-bc07-11e1-9aff-00144feabdc0.html

[14] http://www.bbc.co.uk/news/business-23020718

[15] http://www.kb.cz/en/companies/companies-with-a-turnover-under-60-million/currency-swap.shtml

[16] http://www.investopedia.com/articles/forex/11/hedging-with-currency-swaps.asp

[17] www.sanjeev.sabhlokcity.com/almaak/Termpap/swap-PRESENT.DOC,

[18] Clifford W. Smith, Jr., Charles W. Smithson, and Lee Macdonald Wakeman: The Evolving Market for Swaps

[19] Sivaprakasam, Sivakumar and Anita Mathew, Currency Swaps: An Instrument of International Finance Vol. 21, No. 2, April June 1996, page 1-6

[20] http://www.economywatch.com/currency/currency-swap.html

[21] http://articles.economictimes.indiatimes.com/keyword/currency-swap/featured/2

[22] http://articles.economictimes.indiatimes.com/keyword/currency-swap

[23] http://www.china-briefing.com/news/2013/10/15/china-signs-45-billion-euro-currency-swap-deal-with-eu.html

[24] http://www.china-briefing.com/news/2013/10/15/china-signs-45-billion-euro-currency-swap-deal-witheu.html\#sthash.swdHBkOV.dpuf

[25] http://articles.economictimes.indiatimes.com/keyword/currency-swap/featured/2

[26] http://articles.economictimes.indiatimes.com/2013-08-07/news/41167859_1_currency-swap-agreements-trade-deficit-trade-policy

[27] http://articles.economictimes.indiatimes.com/2013-03-08/news/37561769_1_currency-swap-short-term-liquidity-bhutan-ink

[28] http://www.thejakartapost.com/news/2011/08/13/asean-china-use-bilateral-currency-swap.html

[29] http://www.hurriyetdailynews.com/japan-in-currency-contracts-with-three-asian countries.aspx? pageID=238 \&n ID=5951 \& News Cat ID=344

[30] http://www.indianexpress.com/news/india-in-talks-with-10-countries-for-currency-swap- pacts/1198540/ 